\author{
Кенан Коч \\ (Мугла, Турция)
}

\title{
РУССКИЕ ЗАИМСТВОВАНИЯ В ЮЖНО-КАЗАХСКИХ ДИАЛЕКТАХ КАЗАХСКОГО ЯЗЫКА
}

Общеизвестно, что впервые проблемы, связанные с казахской диалектологией были упомянуты в работах о казахском языке русскими лингвистами, такими как В.В. Радлов (Радлов 1870), П.М. Мелиоранский (Мелиоранский 1897) и В.В. Катаринский (Катаринский 1898).

Тот факт, что в казахском языке имеются слова не только из арабского, персидского и русского, но также из других языков, упоминался уже в первых работах. Более того, в некоторых иностранных языках также имеются казахские и турецкие заимствования, что обосновано в работе Е.Н.Шиповой «Словарь тюркизмов в русском языке» (Шипова 1976) и Н.А.Баскакова «Русские фамилии тюркского происхождения» (Баскаков 1979).

Исследования специфики казахских диалектов были на высшей точке своего развития с 1952 года, так как в этом году много внимания было уделено поиску и собиранию информации о языковых особенностях, на основании Указа Академии наук Казахской ССР (Постановление 1952).

С 1953 года было опубликовано много объемных монографических работ, такие как работы Ж.Доскараева (Досқараев 1946, 1955, 1960) и С.Аманжолова (Аманжолов 1960).

После того как работы Ж. Доскараева и С. Аманжолова были опубликованы, молодые специалисты начали изучение национальных диалектов. В результате, много монографических работ о специальных диалектах были написаны, кандидатские и докторские диссертации были защищены. Тысячи статей были опубликованы. В этих работах диалектологические особенности казахского языка были широко изучены. Некоторые из них были исследованы, как заимствования в определенных регионах (Айдаров 1977; Қалиев 1982; Нақысбеков 1972; Нұрмағамбетов 1974; Сарыбаев 1976; Бектуров 1968; Накысбеков 1963).

Мы считаем, что очень важно углубляться в исторические стороны элементов типов заимствования определенных диалектов, что является основной целью нашего исследования, потому что заимствования проникают в литературу языка через диалекты определенного языка.

Совершенно ясно, что заимствования с особенным значением имеются в каждом языке. Также невозможно представить два общества совсем без взаимоотношений. Хотя это не означает, что заимствование слов из других языков всегда приемлемо, так как если зависимость от иностранного языка слишком велика, в результате родная речь может быть разрушена, а заимствования могут проникнуть в базовый словарный 
запас, заменяя многие основные понятия в родном языке, и, в конце концов, не дать возможность преподавания и обучения родному языку.

Мы считаем, что изучение заимствований языка позволяет узнать историю языка. Мы были свидетелями того, как сильно определение языка с исторической точки зрения близко связано с обществом. Язык, который воспринимается, как основной элемент в культуре может быть обогащен культурными отношениями народа с другим народом и элементы заимствований в старом языке в написанных вариантах являются лучшим примером этого факта. Это значит, что обмен словами между языками, относящимся к разным языковым семействам настоящий феномен, возникший как результат разных межнациональных отношений. Например, взаимодействия между латынью и греческим, казахским и русским, тюркским и персидским, персидским и арабскимлучшие тому доказательства. Более того, вполне можно найти слово определенного народа во всех языках мира, хотя народ, обладающий этим словом, находился далеко от всех стран, даже когда народ совсем неизвестен.

Как правило, основная единица в языковой взаимосвязи - слово. Изначально слова передавались из-за религии, литературных, географических и торговых взаимоотношений. Следовательно, эти заимствованные слова могут быть распределены по некоторым типам: звуковые отношения между языками (ударения в иностранном языке, заимствования в звуковой системе); языковые взаимосвязи в грамматическом отношении (заимствование некоторых грамматических форм, языковой обмен в грамматических аспектах, некоторые функции в одинаковых формах).

Мы можем с уверенностью сказать, что поиск русских элементов в казахском языке с лексической точки зрения всё еще является важной научной необходимостью.

Исследование определенного языка с лексической точки зрения дает нам возможность получить больше информации о жизни народа, его культурных отношениях с другими народами. Через изучение казахской диалектологии мы тоже выявили много информации. Это очевидно, что казахский словарный запас был обогащен культурным и техническим ростом к концу XIX века и изменениями в начале XX века. Мы можем видеть влияние этих событий в некоторых диалектах, в некоторых регионах на примере: нәселке “носилька", лөктір “доктор ", першіл “фельдшер”, зөнтік “зонтик”, жәшік “ящик ”, ләпке “лавка”, күрішке “кружка" и так далее.

В языковом отношении некоторые новые слова могут быть заимствованы через некоторые синтаксические структуры. К примеру, основа "С праздником" переводится как " Мерекенізбен". "Я думаю" это значит личная мысль человека интерпретируется как " Мен ойлаймылн", то есть, никогда не сохраняет порядок слов, как в русском языке. В 
казахском языке, основа “С праздником" произносится как" Мерекеңіз құтты болсын” в первом примере, а во втором примере глагол “думаю” идет в конце предложения "Мен ..............йлаймын”.

Как мы уже упоминали выше, обмен словами, или процесс заимствования слов, объясняется тесной взаимосвязью народов. Изменение в языках и сходство в звуковой системе и в разговорной речи является естественным феноменом для двух народов, находящихся в одном регионе. Элементы узбекского языка в диалектах Южного Казахстана, элементы языка Киргизии в Южном Джамбуле, недалеко от Республики Киргизия, элементы уйгурского в диалекте восточной Жетису, некоторые слова татарского, ногайского и башкуртского языков доказывают этот факт.

В своей работе «"Languages in”», которая была направлена на изучение языковых взаимосвязей, Ю. Веинрич делал ударение на то, что взаимосвязь между языками - непростая вещь. Как оказалось, процесс обмена между языками весьма сложен. Есть три основных понятия об этой проблеме со старых времен. Существует три типа передачи слов из одного языка в другой:

1. Стороннее влияние (adstart, adstratum, Adstratum), то есть заимствование слов может быть объяснено соседством. Отношения между соседями важно для культурного братства между языками, такими как греческий и латынь, китайский и японский, турецкий и персидский. Такие же проблемы имеются в Бельгии, Канаде, Кипре, Швеции и Америке.

2. Влияние снизу (substrat, substratum, Substratum). В таком случае родной язык народа разрушается под влиянием оккупации другого народа, а также элементы родного языка могут встречаться в языке оккупантов.

3. Влияние сверху (superstrat, superstratum, Superstratum). Наоборот, при влиянии сверху язык оккупантов находится под воздействием чужого языка. Некоторые элементы турецкого языка в балканском языке являются отличным примером этого факта. Мы хотим сказать, что взаимоотношения языков не начинаются только как результат устных отношений народов в обществе, но также через прямое воздействие, например, письменность. Лучшим примером этого может служить случай принятия одной и той же религии в двух странах, находящихся вдалеке друг от друга, или влияние одного языка на другой через литературу и культуру.

Определение особенностей процесса приобретения заимствований в казахскую диалектологию является одной из основных задач науки диалектологии, потому что изучение диалектологии с исторической стороны невозможно без различения старых заимствований от заимствований последних периодов. 
Заимствования из арабского, иранского, русского, монгольского и турецкого языка могут встречаться в южных диалектах казахского языка. В особенности русские заимствования занимают важную роль между языками упомянутых народов.

В целом экономические, сельскохозяйственные, культурные и политические отношения русского и казахского народов начались до Октябрьской революции, которая была в начале XX века, когда Казахстан сформировал альянс с Россией. Это событие может быть легко обнаружено в казахском словарном запасе. Русский язык повлиял не только на казахскую литературу, но также на некоторые казахские диалекты. Например, мы может найти много русских заимствований даже в некоторых южно-казахских диалектах, хотя они находятся далеко от России, потому что вторую половину XIX века русские люди проживали там и строили некоторые укрепления и станции. С объединением совхозов и колхозов, русские и казахские люди жили по соседству и имели близкие взаимоотношения друг с другом.

В результате жизни по соседству, и жизни в близком взаимоотношении друг с другом, многие русские заимствования проникли в казахский язык. Лингвисты разделяют эти русские заимствования на два типа: заимствования, проникшие перед Октябрьской революцией и заимствования, проникшие после Октябрьской революции. Перед революцией около сотни слов перенеслись в казахский язык. Передавались ли эти слова из уст в уста из-за слабой развитости казахского письменного языка? Эти заимствования состоят из слов из жилищного хозяйства, блюд, транспорта, и тому подобного. Многие русские заимствования сохранили своё значение, но пишутся по казахским нормам, например: шәлі “шаль", кәмзол "камзол", ояз “уезд", болыс “волость”, қамыт "хомут”, божы "вожжи”, жәрмеңяке “ярмарка”, бәтіңке “ботинок”, керуерт “кровать”, сот “суд” т.п.

Тем не менее заимствования, которые проникли после революции были словами, связанными с современным оборудованием, вещами из домашнего быта, одеждой, сельским хозяйством, наукой и техникой, и использовались в повседневной жизни. Болыс “волость”, губерния "губерние", қазына “казна ", обыльлс “область", старшын "старшина", com "судь", уез "уезд" - имеют связь с государственными делами, бөрене "бревно", бірішке “бричка", кірпіш “кирпич”, “мәтке, арқалық, қары”, учаске "участок", үстел "стол", шолан "чулан " из домашнего обихода, культурно-экономические слова: әртіс "артис", гәзіт "газет”, доқтыр “дәрігер" “доктор", зауыт “завод”, жәрмеңке "ярмарка”, жсрнал “журнал”, концерт "концерт", көлес "купец”, лозунге "лозунг”, мәшина “машина", кейтан арба "паэтон ”, пелщер "фельдшер", пойьз "поездь", сәмөлет "самолет", тыйатр “театр" и также повседневные слова: барқыт - "бархат", бөлке "булка", бөкебай - "пухавой”, сәтен "сатин”, сухар "сухари", плуш “плюш”, камаубай, кәшебай “кашевка”, кәрзеңъке 
“корзинка”, кемірік “конфорка”, керәсін “керосин”, ләмпә “лампа“, ләпке “лавка", мәйкі- "майка”, нәсіелке “носилки”, құамыт “хомут”, тауар “товар”, тесе- “тиски”, ьззрай “субре”, самаурын "самовар ”, сеп "цепь”, спешке “спичка”, партық “фартук”, слова имеющие отношение к военным властям, жандарал “жандарал”, пәлкеунік “полковник”, полковой “полковой”, салдат "солдат", сома “сумма”, шот - “счет”, ылаука - “лавка” и т.д.; слова, связанные с сельским хозяйством: әгроном/ агроном "агроном", бригат - “бригада", бөстекі “пустяки”, құоққоз “колхоз”, кәртошка “картофель”, кілетші “клеть”, сапқ̧оз “совхоз”, пәстөк "пастух", пәмілдәр “помидор", перме “ферма", сушелка “сушилка", ізбене “звено”, и т.д., слова, связанные с ведением счета: абарот-обрат, бувалтыр "бухгалтер”, пут "пуд”, сентнер “центнер", тона "тонна”, балшабай “фальшивый”, и т.д.; слова, связанные со спортом: пизкультуре “физкультура”, турнік “турник”, шақмат “шахматы”.

По материалам, данным выше мы можем поделить русские заимствования на две группы: родные русские заимствования и иностранные заимствования, проникшие в казахский через русский.

Все эти заимствования характерны для разговорной речи в Южном Казахстане. Поэтому, когда мы говорим о лексическом взаимоизменении важно помнить о двух вещах:

1. Заимствования проникли в казахский язык путем взаимотношения напрямую, т.е. через прямой контакт между местными казахами и русскими людьми.

2. Заимствования, которые проникли в казахский язык, в свою очередь, были заимствованы из других иностранных языков.

Мы уже говорили о том, что Россия повлияла на местную разговорную речь, хотя влияние на устную речь было слабее, чем влияние на литературу. Хотя было много русских заимствований в разговорном языке, они не могли обогатить казахскую литературу. Например, русские заимствования бедре, істен, әкүршік, бәкіс, лес ни разу не были использованы в литературном языке, хотя они были широко употребляемы местными жителями в определенных регионах.

В заключение, мы можем сказать наверняка, что для того, чтобы определить лингвистический раздел казахской диалектологии и литературного языка, очень важно установить историю заимствованных элементов. Потому что, с исторической точки зрения, русские, иранские, арабские, монгольские заимствования никогда не влияли напрямую на литературный язык, хотя они влияли на разговорную речь. Также необходимо разделять старый словарный запас от современного словарного запаса, которые были обогащены через заимствования других языков. 
Во-вторых, эта проблема близко связана с двуязычностью языков, втретьих, исследование элементов заимствований заставляет нас смотреть в историческую этимологию заимствований. В-четвертых, пока мы группируем казахский разговорный язык, мы должны понять, были ли эти заимствования способны меняться или перемешиваться.

Мы были свидетелями того, как жители Южного Казахстана используют русские заимствования, которые тесно связанны с ежедневной жизнью. Также, мы должны упомянуть, что в большинстве случаев, проникли только потому, что люди в Южном Казахстане имели близкие сельскохозяйственно-экономические отношения с русскими людьми.

В результате нашего исследования, мы должны признать, что русские заимствования характеризованы, как лексические диалектизмы, которые близко связанны с ежедневной жизнью. Соответственно, эти лексические заимствования должны быть поделены на лексические и семантические группы.

\section{Литература}

Айдаров, Т. (1977) Лингвистикалық география. Өзбекстан қазақ говорларының лексикасы. Алматы, 144 б.

Аманжолов, С. (1959) Вопросы диалектологии и истории казахского языка. Алма-ата.

Бектуров, Ш. (1968) Кызылординский говор казахского языка. Авт. дисс. канд. филол. наук. Алма-ата.

Баскаков, Н.А. (1979) Русские фамилии тюркского происхождения.

Досқараев, Ж. (1960) Арыс говорының лексикалық ерекешеліктері. // ҚҚТ мен ДМ. 3-шығуы.

Досқараев, Ж. (1946) Краткий очерк о южном диалекте казахского языка. // Известия АН КазССР, серия филологическая. Вып. 4.

Досқараев, Ж. (1955) Қазақ тілінің жергілікті ерекшеліктері. /Лексика / II бөлім, Алматы.

Қалиев, Г. (1982) Қазақ говорларындағы диалектілік сөз тудыру. Алматы. 168 б.

Катаринский, В.В. (1898) Грамматика киргизского языка. Оренбург.

Кеңесбаев, І.К. - Мұсабаев, Ғ. (1962) Қазіргі қазақ тілі /Лексика, фонетика/. Алматы. 114 б.

Мелиоранский, П.М. (1897) Рец. на «Катаринский В.В.. Грамматика киргизского языка». Оренбург. // Записки восточного отделения русского археологического общества, т.XI. 1897-1898. с.363-364.

Нақысбеков, О. (1972) Қазақ тілінің оңтүстік говоры. Алматы. 176 б.

Накысбеков, О. (1963) Языковые осебенности казахов Чуйской долины. Авт. дисс. канд. филол. наук. Алма-ата. 
Ниязғалиева, А.Ә. (1993) Қазақ сөйленістеріндегі орыс тілінен енген сөздер. Филология ғылымының кандидаты дәрежесін алу үшін жазылған диссертация. Алматы. 12-13.

Нұрмағамбетов, Ә. (1974) Түркменстандағы қазақтардың тілі. Алматы. 167 б.

Постановление Прездиума АН КазССР об итогах дискусси по языко знанию (1952) // «Вестник АН КазССР», №6, с. 19-23.

Радлов, В.В. (1870) Образцы народный литературы тюрских племен, живущих в Южной Сибири и Дзунгарской степи, ч. Ш.Киргизское наречие, СПб.

Сарыбаев, Ш. (1976) Казахская региональная лексикография. Алма-Ата, $216 \mathrm{c}$.

Шипова, Е.Н. (1976) Словарь тюркизмов в русском языке.

Doğan, Aksan (1987) Her Yönüyle Dil Ana Çizgileriyle Dilbilim C.1, TDK Yay., Anakara.

Weinreich, U. (1977) Sprachen in Kontakt, Ergebnisse und Probleme Zweisprachigkeit, München. 